\title{
Foreign Cloth, Local Habits: Clothing, Regalia, and the Art of Conversion in the Early Modern Kingdom of Kongo
}

\section{Cécile Fromont $^{1}$}

ABSTRACT: From their king's decision to embrace Catholicism at the turn of the sixteenth century to the advent of imperial colonialism in the late eighteen hundreds, the men and women of the central African kingdom of Kongo creatively mixed, merged, and redefined local and foreign visual forms, religious thought, and political concepts into the novel, coherent, but also constantly evolving worldview of Kongo Christianity. Sartorial practices and regalia in particular showcased the arfful conversion of the realm under the impetus of its monarchs and aristocrats. In their clothing and insignia, the kingdom's elite combined and recast foreign and local, old and new, material and emblems into heralds of Kongo Christian power, wealth, and, eventually history. I propose to use the concept of the space of correlation as a key to analyze these elaborate, and constantly evolving religious, political, and material transformations through an attentive focus on cultural objects such as clothing, hats, swords, and saint figures.

KEYWORDS: Kongo kingdom. Clothing. Space of Correlation.

RESUMO: Da decisão do rei de abraçar o catolicismo na virada do século XVI até o avanço do colonialismo imperialista do final do século XIX, os homens e mulheres do reino do Congo na África central criativamente misturaram, fundiram e redefiniram formas visuais locais e estrangeiras, pensamento religioso e conceitos políticos numa visão de mundo original, coerente e em constante evolução do cristianismo congo. Práticas de vestimenta e, em especial, insígnias reais demonstram a astuciosa conversão do reino sob o ímpeto de seus monarcas e aristocratas. Através de suas vestimentas e insígnias a elite do reino combinou e remodelou o estrangeiro e - local, o velho e o novo, materiais e emblemas nos arautos de poder, riqueza e, inevitavelmente, história cristã no Congo. Proponho utilizar o conceito de espaço de correlação como elemento-chave para analisar essas elaboradas transformações religiosas, políticas e materiais, em evolução constante, de forma a estabelecer um foco minucioso em objetos culturais tais como indumentária, chapéus, espadas e imagens religiosas.

\author{
1. Associate professor in Art \\ History at the University of \\ Chicago.E-mail:<fromont@ \\ uchicago.edu>.
}

PALAVRAS-CHAVE: Reino do Congo. Indumentária. Espaço de Correlação. 
A crowd of men clad in colorful fabrics, weapons held high, marches downhill from the outskirts of a town towards a Capuchin friar and his entourage. (Figure 1) Their richly attired leader walks one step in front of the group in the shade of a red umbrella that an attendant diligently holds above his head. The shade, the attentive servant, as well as elaborate items of regalia and clothing set the man apart from the rest of the group. He wears an mpu cap on the head, an nkutu net over the shoulders. He carries a wooden staff in his left hand, and many bracelets and anklets adorn his arms and legs. As he steps, a fringed wrapper of thick and colorful textile, fine raffia cloth or silk brocade undulates around his legs and a brilliant red coat embroidered with the insignia of the Order of Christ hangs behind his back. The second man in command, under another crimson shade and also with a red coat draped on his left shoulder has chosen a cotton wrapper checkered in blue and red. Each of the attendants grouped around the two men shows off a different combination of clothing and regalia according to his rank. Some wear nkutu nets, others, coats of various hues, and all carry swords or muskets. To the right of the image, the Franciscan friar coolly stands under a simple umbrella to face the welcoming party. Behind him, two mestres, interpreters and leaders of the Church, wear their uniform composed of a white cloth draped over one shoulder. Members of the elite themselves, they are also richly attired.

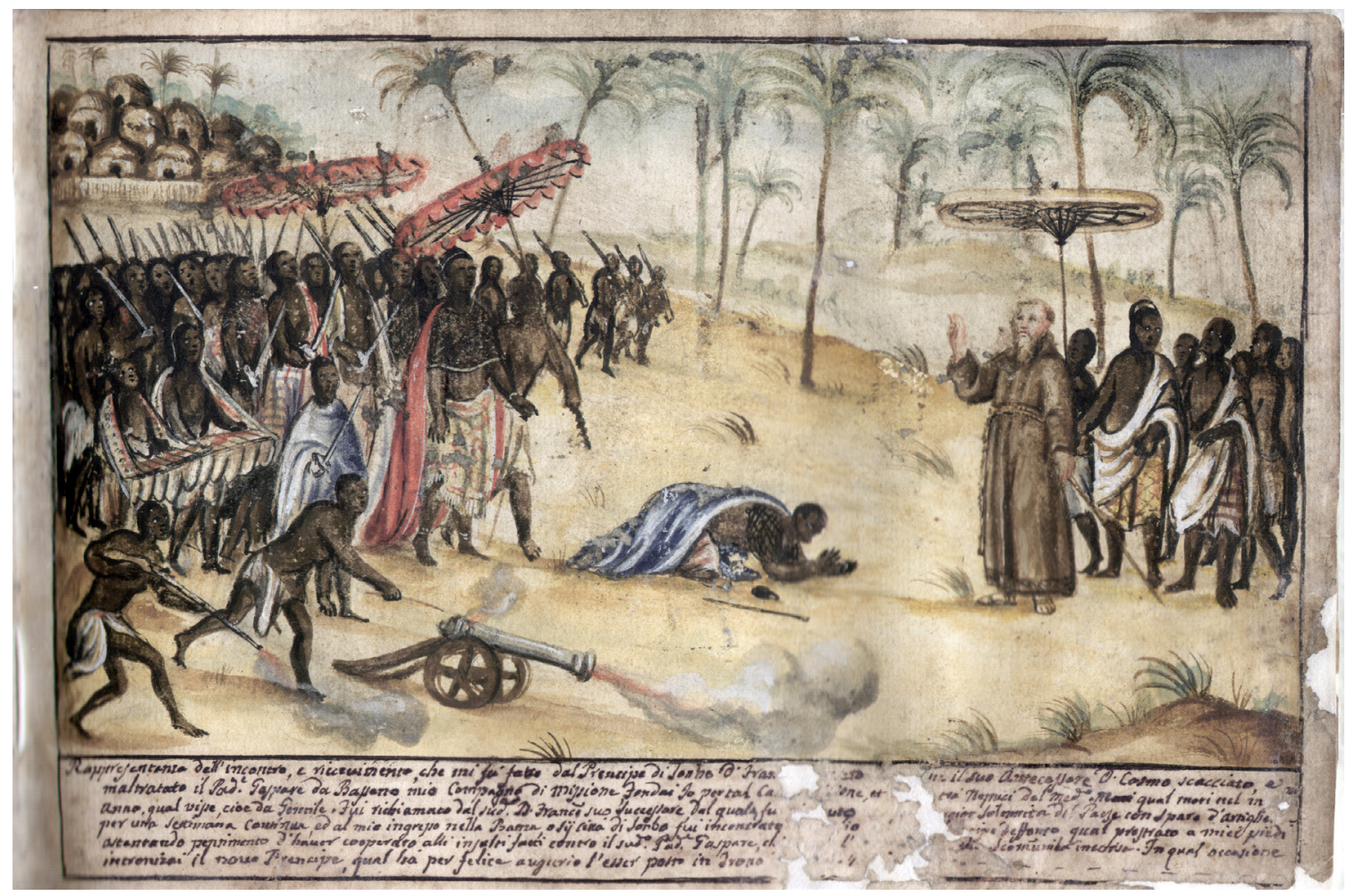

Figure 1 - Bernardino d'Asti. Reception of a capuchin missionary by a local ruler. Italy, ca. 1740. Watercolor on paper, 19,5 $28 \mathrm{~cm}$. Biblioteca Civica Centrale, Torino, MS 457, fol. 18. Photograph copyright: @ Settore Sistema bibliotecario urbano della Città di Torino. 
This vignette comes from the Missione in Prattica, an illustrated manuscript composed around 1750 by Bernardino d'Asti, a veteran of the Capuchin Order's central African mission to train and educate European novices about apostolic work in the Kongo. The image, as the other watercolors of this primarily visual practical guide brings to life the visual, material, and social environment of early modern Kongo Christianity. Together, they present unexpected tableaus in which Christian objects, rituals, and symbols seamlessly meld with African imagery, practices, and emblems. The characters in the watercolors inhabit a space that, for friar Bernardino's audience in eighteenth century Italy as well as for viewers of his works today, challenges preconceptions about Africa. Instead of a strange land alien to European ideas, objects, and practices, it is a cosmopolitan, visibly Christian landscape that opens up before our eyes. This is the Kingdom of Kongo, a realm that had at the time of the paintings professed Christianity and engaged with the visual and material cultures of Europe and the Atlantic world at large for nearly two hundred and fifty years. From their king's decision to embrace Catholicism at beginning of the sixteenth century to the time of Bernardino and beyond, men and women of the Kongo creatively mixed, merged, and redefined local and foreign visual forms, religious thought, and political concepts into a novel, coherent, and constantly evolving worldview that I call Kongo Christianity. ${ }^{2}$

The kingdom of Kongo was a centralized polity that was founded in the thirteen hundreds and extended south of the Congo River over the western part of today's Democratic Republic of the Congo and Angola. ${ }^{3}$ Its political organization centered on the person of the king who ruled with absolute power from his capital city over large territories through the governors he sent from his court to the provincial capitals. The kingdom entered into European history in the 1480s with the arrival on its shores of Portuguese explorers and clerics in search of the maritime passage to India and of new allies for Christendom. ${ }^{4}$ In the first decade of contact between the realms of Kongo and Portugal, hostages were exchanged, embassies dispatched, and a cordial diplomatic relationship established. ${ }^{5}$ The result of this early contact with Europeans was the conversion of the Kongo monarch to Catholicism and his decision to impose the new faith as the kingdom's state religion. ${ }^{6}$ That decree was met with a mix of enthusiasm and opposition, but, as discussed below, it eventually prevailed and opened a new era in the history of west central Africa, defined by its involvement in the commercial, political, and religious networks of the early modern, Christian, Atlantic world. It is crucial to underline that the kingdom remained independent throughout the early modern period, free of European colonial domination if shaken at all levels of its social and political organization by the disruptive effects of the slave trade.

The watercolor in Figure 1 thus records a scene that unfolds in a kingdom whose Christianity dated back centuries, and in which a powerful provincial ruler makes a conspicuous display of his standing not only as a central African ruler but also as a Catholic knight. He appears grandly dressed in the cosmopolitan outfit of the Kongo Christian elite, in a mix of textiles and insignia derived from both local
2. For a discussion of the Capuchin watercolors see Fromont (2011a). The material from this article, including the idea of Kongo Christianity come from Fromont (2014).

3. The geography of the Kingdom of Kongo has been discussed in the first chapter of Hilton (1985).

4. For a recent discussion of Portugal overseas explorations see Bethencourt; Curto (2007).

5. The early history of the encounter between Portugal and the Kongo is told for example in the texts of Rui de Pina, chronicler for the royal house of Portugal. See the critical edition by Radulet; Pina (1992).

6. An overview of the period based on careful study of the primary sources maybe found in Leguzzano (1982-1983). 
7. On the dispute see Leguzzano (1982-1983). See also Bernardino d'Asti's version in his Vatican manuscript D'Asti (ca.1750). More details appear in Archivio Storico de Propaganda Fide, SOCG, vol. 721, ff. 298, 301. The text of the vignette is damaged, so the identity of the prostrated man is unclear, but it likely is a relative or close associate of the dead prince.The six lines under the image read: "Rappresentanza dell'incontro, e riccevimento, che mi fú fatto dal Prencipe di Sonho d. Franc[...] il suo antecessore d. Cosmo scacciato e maltratato il $\mathrm{Pad}^{\mathrm{e}}$ Gaspare da Bassano mio compagno di missione, fondai io per tal $\mathrm{Ca}[\ldots .$.$] ione, et [....] tra$ nemici dal med $^{\circ}$ Mani qual mori nel $\mathrm{m}[\ldots]$ anno, qual visse, cioe da Gentile. Fui richiamato dal sud ${ }^{\circ} \mathrm{d}$. Franc[esc]o suo successore dal quale fu [...]to [con la mag]gior solemnita del Paese con sparo d'artiglie[ria] per una settimana continua, ed al mio ingresso nella Banza, $s^{\circ}$ sij Cittá di Sonho, fui incontrato $[\ldots]$ io $[\ldots]$ deffonto qual prostato a miei piedi ostentando pentimento d'haver cooperato alli insulti fatti contro il su$\mathrm{d}^{\text {o }} \mathrm{Pad}^{\mathrm{e}}$ Gaspare, $\mathrm{ch}[\ldots]$ 1 '...] scom[m]unica in corsa. In qual occasione intronizai il novo Prencipe, qual há per felice augurio l'esser posto in Trono [...]" The manuscript including this watercolor is available fully online at $<$ http://www.comune.torino.it/cultura/biblioteche/iniziative_mostre/mostre/missione/ prefazione.html> and also partially in Guattini; Carli; Surdich (1997).

8. Here I used the term space in the sense of "espace" in French referring to an extent or a domain that is both localized and specifically defined. The phrase is partly inspired by Tom Cummins' discussion of images as "sites of correla- and foreign sources. While his mpu cap and nkutu shoulder net draw from central African practices and symbolism, his coat and insignia of the Order of Christ, as the swords held by his most prominent lieutenants, ultimately derive from a European imagery of nobility and prestige.

The watercolor and the scene it records celebrate the return of the Capuchin mission to Soyo a few years after a disagreement with the former ruler Cosme Barreto da Silva had driven the friars out of the region in 1743. The dispute emerged around the Prince's right to marry one of his nieces against Catholic kinship rules. In the image, the missionary gazes up to the Prince with a gesture of blessing and salutation and conspicuously overlooks the man lying apologetically at his feet. The prostrated penitent is also richly outfitted in a thick blue coat, and an nkutu net. He respectfully took off his mpu bonnet and dropped his wooden staff, now lying on the ground next to him. The Prince, in turn, looks back at the priest but points to the man on the floor. The damaged text of the page partly explains the exchange. Don Francesco, it tells us, the new ruler of Soyo presents to Bernardino a repentant associate of the former Prince, as a token of his own dedication to the Capuchin mission and in a conspicuous display of might over his people, even of the highest social rank. The friar, in turn, haughtily accepts the homage and apology. The chime of marimbas complete the rich multi-sensory display of prestige, interrupted by artillery fire resoundingly showcasing the Prince's access to the commercial and technological networks of the Atlantic world and his conspicuous consumption of gunpowder, a most precious and sought after commodity, literally blown into smoke for show here in the foreground?

Spaces of Correlation

Kongo Christianity took shape from the sustained encounter between central African and European religious thought, visual forms, and political systems; an encounter that took place within a set of cultural objects - narrative, artworks, performances - that formed what I call in my broader research spaces of correlation. ${ }^{8}$ Spaces of correlation as I conceive them provide common grounds in which cultural agents can bring together ideas belonging to radically different realms, confront them, and eventually turn them into interrelated parts of a new system of meaning. My interest in the idea of the space of correlation derives from its ability to examine phenomena emerging from varied historical circumstances and following mechanisms of interactions beyond dialectical relationships. The idea allows to center our reflection on the syntactic strategies put to play in the cultural objects - artworks, discourse, text - through which change is expressed and enacted. It does not presume the political tenor of these strategies that can be empowering responses to oppression but also in other contexts the result of curiosity or opportunism. Looking at specific forms of cultural production and interrogating their genealogies and the aesthetic choices of their makers allows to consider the transformative powers of choice and contingency in contrast to the often agentless and teleological perspectives of ideas 
of syncretism or acculturation. In addition, it helps avoid the pitfall of creating broad and artificially coherent groups holding for instance Europeans or Africans as single entities without inner diversity of class, gender, or else. Rather, it singles out and considers only the relevant traits from each group that are called upon and put to play in the process of change.

\section{Kongo Christian Fashion}

The defining trait of Kongo Christian regalia, the space of correlation on which this essay focuses, revolved around artful juxtapositions of local and foreign elements, combined and redefined into a new look. The 1591 engravings illustrating Filippo Pigafetta's edition of Portuguese merchant Duarte Lopes' eye witness accounts of the region are the earliest European depictions of Kongo Christian sartorial practices. These partly fanciful, partly accurate images come in sharp focus in a series of oil studies painted in Brazil around 1642. Albert Eeckhout, court painter for the governor of Dutch Brazil Johan Maurits van Nassau seized the likenesses of the five diplomatic envoys that the ruler of Soyo sent to Recife around 1642, in five images of men of varying rank within the central African elite, offering a detailed visual record of upper class clothing practices of seventeenth century Kongo. ${ }^{9}$ The oil on paper paintings are part of the Theatri Rerum Naturalium Brasiliae, a group of images collected and edited in five volumes by the physician Christian Mentzel for the Elector of Brandenburg who had bought the series in 1652 from their original commissioner, the former governor of Dutch Brazil, Johan Maurits van NassauSiegen. ${ }^{10}$ After many movements along the centuries, the volumes are now in the collection of the Biblioteka Jagiellonska in Krakow, Poland. " portraits of the nobles are part of the third volume of the Theatri Rerum; they appear on pages 1, 3, 5, 9 and $11 .{ }^{12}$ (Figure 2 a and b) The older men are almost certainly Miguel de Castro, Bastião de Sonho and António Fernandes, the three ambassadors sent from Soyo to Recife, high ranking and well educated nobles, who could converse with the Dutch officials in Latin. ${ }^{13}$

Eeckhout composed the portraits of the five emissaries who visited the Dutch court in Recife in 1642-1643 as part of his duties as official painter. ${ }^{14}$ The paintings did not stage the Kongo ambassadors in elaborate compositions but rather, as studies, seized their appearance in a documentary mode. The three high ranking men wear colorful mpu caps adorned with shells as well as metal chains, medals, crosses and long strings of coral beads favored across the kingdom. ${ }^{15}$ (Figure 2a) Two of the three men have draped great lengths of heavy dark wools over their bare shoulders and combined them with wrappers of the same fabric or made of central African dark dyed patterned cloth. ${ }^{16}$ The third ambassador, probably ready to dance in the typical Kongo martial performance the men staged in Recife, sports a shorter, lighter wrapper of yellow brocade that leaves his bust and arms uncovered and ready to grab his bow and arrows in the course of the acrobatic dance. ${ }^{17}$ All three tion" in colonial legal contexts. See Cummins (1995).

9. At least two embassies were sent from the Kongo during that year one from the king and the other from the ruler of Soyo. See the description of the diplomatic visits in Baerle; Brandão (1940).

10. Eeckhout; Mentzel (1637-1644b).

11. For a brief description of the Theatri and their adventuresome life see Artelt (1964) and Brienen; Eeckhout (2006).

12. Volume III of the Theatri holds the call number Libri Picturati A 34 in the Jagiellonian Library. Eeckhout; Mentzel (16371644a). Note that the title of the images were given by Mentzel, the compiler of the Theatri and do not reflect Eeckhout observations. The reference to Chile in the text describing two of the ambassadors "principum quidam Chilensium" and "alius Chilensium" comes from the expedition conducted by Dutch naturalists to the Andean region and which drawings are included in the Theatri. Note also that page 7 of the volume has been cut out; it might have depicted a third attendant to the three ambassadors.

13. Heywood; Thornton (2007).

14. See the description of the diplomatic visit in Baerle; Brandão (1940). See the discussion in Brienen; Eeckhout (2006).

15. Although zimpu are often white, colored ones are also mentionned see for example Bontinck; Roma (1964). Lopes mentions a yellow and red cap in Lopes; Pigafetta (1591). The duke of Bamba wears a red cap with strips of gold in Guattini; Carli; Surdich 

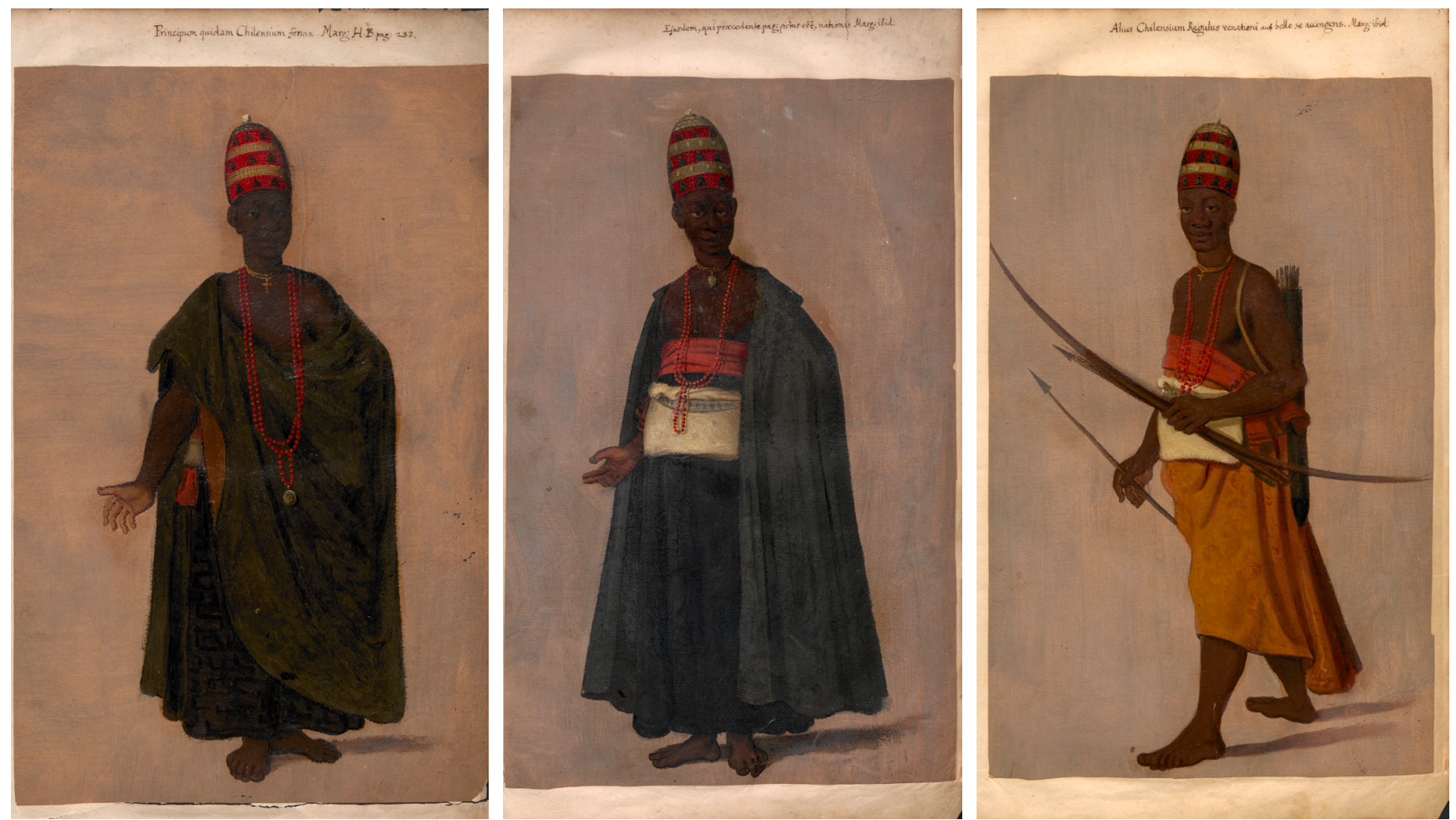

Figure 2 a - Albert Eeckhout. Portrait of a Kongo Ambassadors to Recife, ca. 1637-1644, oil on paper, 30 × $50 \mathrm{~cm}$, Jagiellonian Library, Krakow, Libri Picturati 34, folio 1, 3, 5. Photograph courtesy of the Jagiellonian Library Photographic Services.

Figure 2 b - Albert Eeckhout, Portrait of a Kongo Ambassadors to Recife, ca. 1637-1644, oil on paper, $30 \times 50$ $\mathrm{cm}$, Jagiellonian Library, Krakow, Libri Picturati 34, folio 9 and 11 . Photograph courtesy of the Jagiellonian Library Photographic Services.
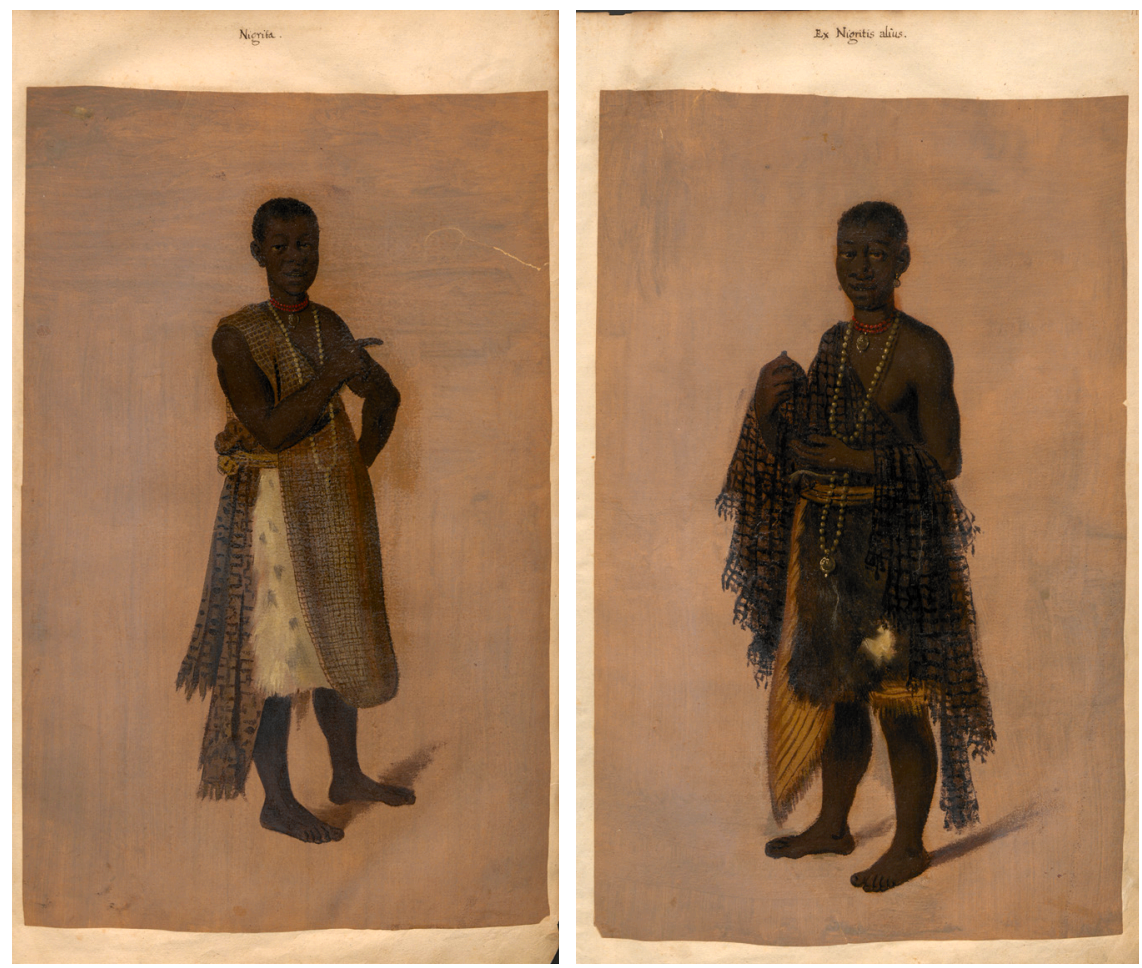
senior legates cinched their waist with a red sash, a neatly folded animal pelt, and in two cases a band of white and blue checkered cotton. Their bare-headed attendants draped on their shoulders net-like textiles resembling nkutu. Their jewels, while still opulent, are less exuberant than those of their senior counterparts. They wear simpler wrappers of Kongo cloth adorned with loosely hanging, rather than neatly folded cat skins.

From Lopes' 1591 descriptions, to Eeckhout's 1642 paintings, and up to friar Bernardino's 1750s watercolors, a consistent image of the Kongo Christian elite regalia thus appears across time in these European accounts that, significantly, closely correspond to the findings of archeological explorations of the kingdom of Kongo. The 2012-2013 reexploration of the Ngongo Mbata cemetery in the former province of Mbata, and the new excavation of an elite cemetery at Kindoki, in what was once the Nsundi province, uncovered the remains of men and women interred in the late eighteenth and early nineteenth century prepared to face the other world armed and adorned with swords, crucifixes, medals, and textiles echoing those worn by their counterparts in the watercolors. ${ }^{18}$

The Art of Conversion

These regalia and sartorial practices that endured in their main traits over the centuries encompassed a political and religious dimension that arched back to the reinvention of the Kongo Kingdom as a Christian land by his first great Catholic king Afonso. In a foundational narrative that he outlined in a series of letters to his vassals and to the Pope, Afonso exposed what he intended to become the official narrative of his ascension to the throne. The young Christian prince who had converted in his youth, the story told, seized the Kongo crown after a bitter succession struggle against his heathen brother. Outnumbered and at the verge of defeat, Afonso called upon the Warrior Saint James before the final and surely fatal assault. Against all odds, the pious Prince emerged victorious from the fight thanks to the miraculous apparition of Saint James and a prodigious cavalry, who rooted the infidels under the resplendent sign of the Cross that miraculously branded the sky of the decisive battle. ${ }^{19}$

With this narrative, the new king placed his rule in the historical and symbolic realm of Christendom, presenting himself as a Christian prince fighting alongside Saint James and one for whom the Cross of Constantine reappeared. Yet, the story also inscribed Christianity into central African mythology by likening Afonso to Lukeni, the original founding hero of the Kongo kingdom. Old and new creation myths presented a civilizing hero, who is able to seize leadership of the Kongo through military might, thanks to the control of iron, - smelting technology for Lukeni and prodigious sword bearing cavalry for Afonso, and eventually brings to the land a new form of wisdom, Kongo cosmology in the earlier case and Christianity in the other. The bold and innovative narrative of Afonso proved successful and not only became
(1997). For references to coral beads see for example Piazza (1973), Merolla da Sorrento; Piccardo (1692). Dapper also mentions the juxtaposition of metal chains and red coral or red beads in Dapper (1668). Other references to coral beads as part of the royal regalia in Roma; Bontinck (1964).

16. Francesco da Roma describes in 1648 the popular black dying process of Kongo local cloth, see Roma (1648).

17. Nieuhof (1682).

18. See also the closely related image of Kongo elite in Merolla da Sorrento; Piccardo (1692). The print is on page 177, number 14 . For archeological findings about the kingdom see Vandenhoute (1972-73). See also the findings from the KONGOKING project, including Clist et al. (2015).

19. Fromont (2011b). 
20. See for example Jadin (1970). See also Jadin (1963).

21 . The coat of arms appears in Godinho (1528-1541).

22. The Kongo creation myth fits here with Bantu myths in general see Heusch (1972), Vansina (1966).

23. Fromont (2011c). an integral part of Kongo mythology but also successfully ensured the standing of the Kongo as an independent Christian kingdom in the eyes of European powers. ${ }^{20}$

The coat of arms of the Kongo composed in Portugal almost certainly at the demand of Afonso, provided a key visual dimension to the narrative. In the oldest visual record of the escutcheon from a 1548 Portuguese armorial, a silver cross appears on a sky blue stripe, and iron swords carried by the arms of armored knight stand out over a blood red background (Figure 3). ${ }^{21}$ The heraldic sign makes the symbolic weight of cross and sword clear. What is more, both motifs not only encapsulated the key moments of the story but also became essential points of correlation between local and foreign conceptions of power, prestige, and ideas of the supernatural. The swords linked the new regime that Afonso inaugurated not only to the intervention of the Christian Saint James. They associated it, through their material and even in their mostly European form, with local semantic and symbolic associations between iron, power and kingship. ${ }^{22}$ The cross is the space in which Afonso brought together and recast in a new light central African and Christian conceptions of the permeability of life and death associated in both cases with the cruciform sign. Large and elaborate crucifixes materialized this correlation, bringing together and articulating the narrative of the death and resurrection of Christ with the abstract conception of cyclical demise and rebirth also associated in central Africa with the sign of the cross (Figure 4). ${ }^{23}$

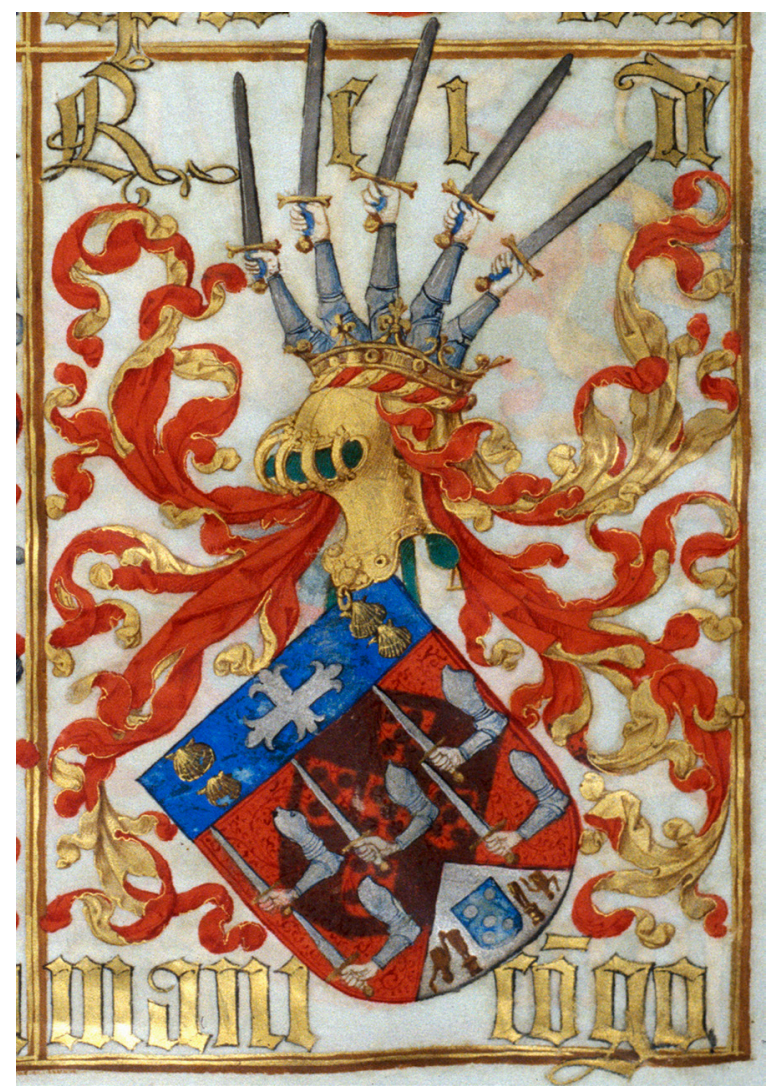

Figure 3 - Rei de Manicongo, Coat of Arms of the King of Kongo. António Godinho. Livro da nobreza e perfeiçam das armas. Portugal, 1528-1541. Pigment and Gold on parchment, $430 \times 320 \mathrm{~mm}$. PT/TT/ CR/D/A/1/20, Direção-geral dos Arquivos - Torre do Tombo, Lisbon, MS CF-164, folio 7 (detail). Photo courtesy of ANTT. 


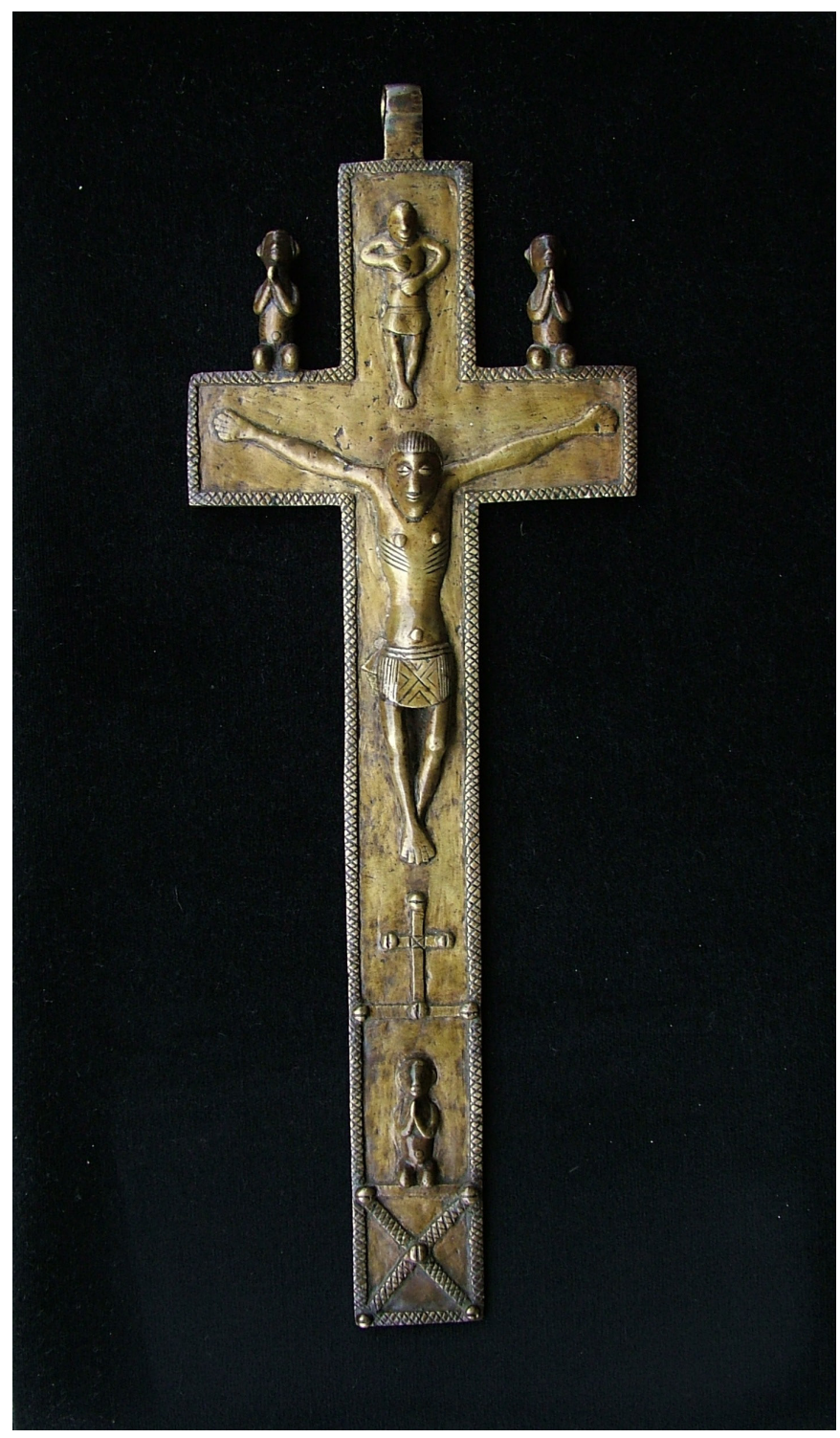

Figure 4 - Kongo Crucifix. Unknown artist. Possibly 18th century. Kongo Kingdom. Brass, $40 \times 20 \mathrm{~cm}$. Private collection (Photograph of the author).

These crucifixes served as part of the Kongo Christian regalia, alongside large iron swords that mixed and merged European ideas of aristocracy and central African conceptions of power, strength and fortitude associated with iron itself. The anthropomorphic weapons echoed the crucifixes but also the look of their wearers altogether. Decorative nails, engraved incisions and openwork enhance for example the guard of this sword now in Berlin's Ethnology Museum. (Figure 5a) The handle cover made of organic material has disintegrated, but the metallic decoration at its top indicates that even in its original form, the sword suggested rather than depicted the human figure. Four pegs, each enhanced with a single slit attach the guard to the blade and form a cross on the chest of the figure, seemingly on top of a garment whose triangular shape recall the nkutu net seen hanging on the shoulders of the 
24. Fromont (2014), Kaplan (2010). dancing warrior in Figure 5b. From there, broad shoulders turn into thin arms, fists planted on hips at the level of a sash attached with pyramidal pegs. A thick strip of metal hangs over the arms of the figure as a heavy coat, enhanced with undecorated nails arranged in diamond or cruciform pattern. The thick untailored piece of fabric used as a cloak echoes that captured in polychrome marble in the funerary bust of Antonio Manuel, an ambassador of the king of Kongo who died in Rome in 1608.24 (Figure 5c) The sword's coat ends in decorative openwork forming two medallions pierced with a cross that could be that of the Order of Christ, effectively rendered with its bi-colored design through negative and positive space. Small jewel-like rings hang from the crosses. Fishbone patterns and $x$-shaped crosses decorate the shoulders and the belt. Decorative nails with carefully lined slits, engraved incisions on the metals, $x$-shaped crosses, and determined arm gesture close the loop that linked through design and a common underlying political, mythical, and religious message the swords of status, their elite Kongo Christian owners, and the crucifixes. At once European and Kongo in shape and meaning, swords, crucifixes, and regalia materialize the connection between power and devotion at the core of the Kongo Christian political system.

Figure $5 a$ - Sword of Status. Kongo Kingdom, 16th - 19th century, iron, height: $55 \mathrm{~cm}$. Ethnological Museum - Staatliche Museen zu Berlin, inv. III C 44945. Photograph from Jill Rosemary Dias. África: nas vésperas do mundo moderno (Lisbon, 1992, p. 141).

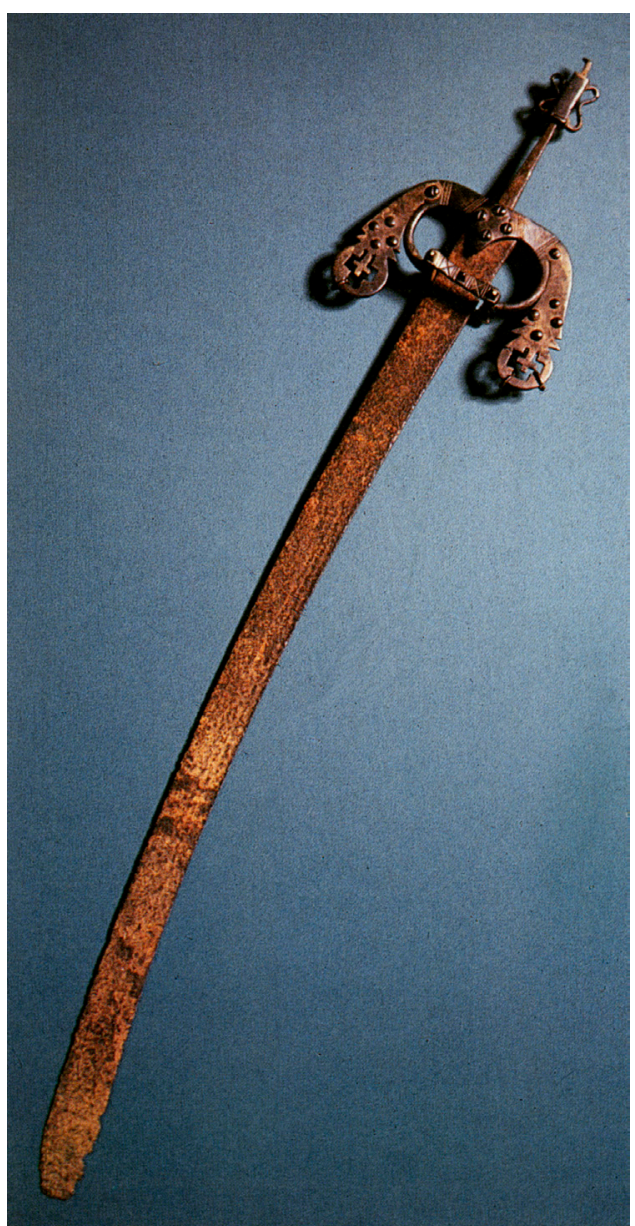

Anais do Museu Paulista. v. 25. n.2. Mai.-Ago. 2017. 

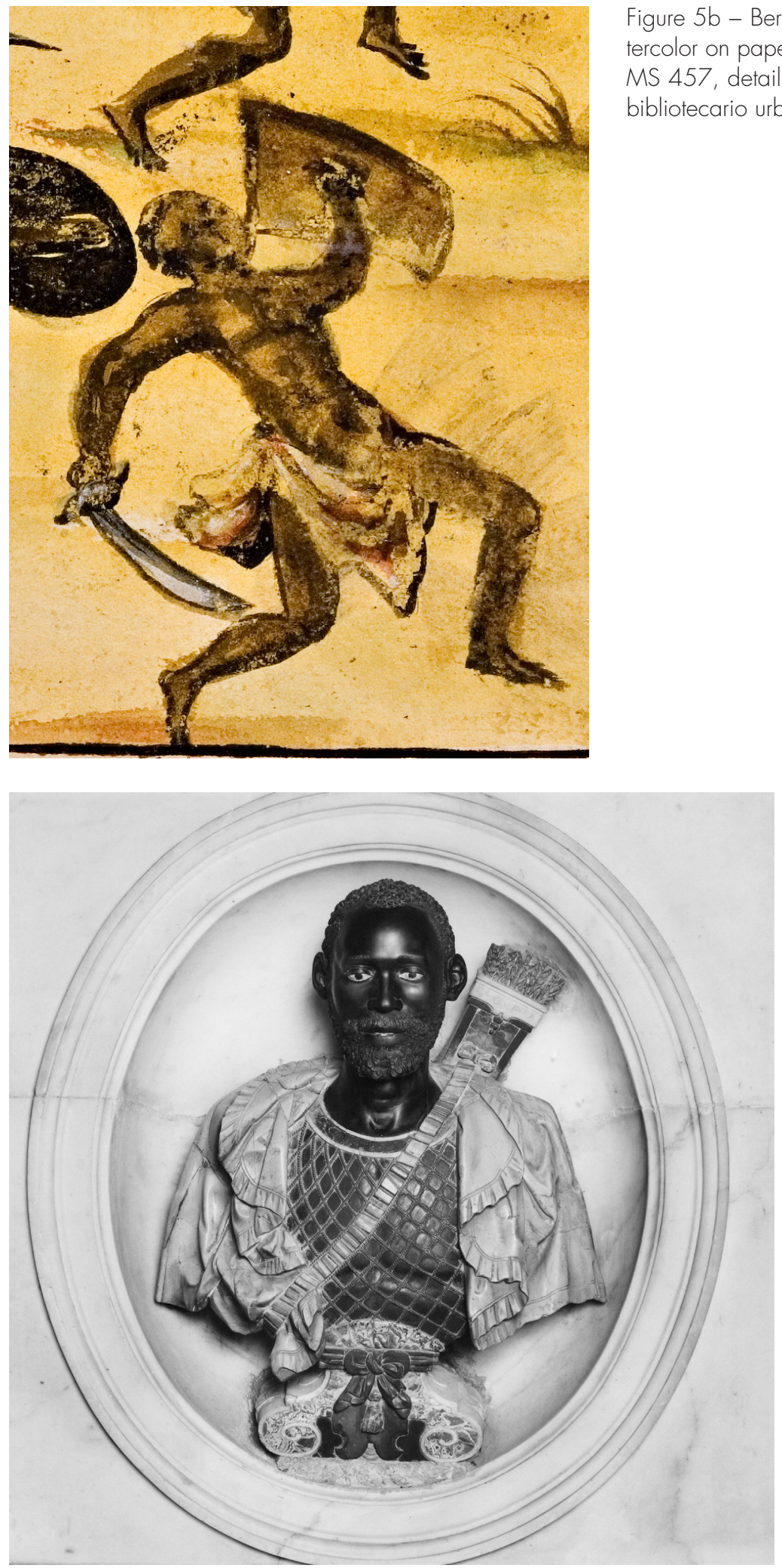

Figure 5b - Bernardino d'Asti. Sangamento dancer. ca. 1750. Watercolor on paper, 19,5 $\times 28 \mathrm{~cm}$. Biblioteca Civica Centrale, Torino, MS 457, detail of fol. 18. Photograph copyright: (C) Settore Sistema bibliotecario urbano della Città di Torino.
Figure 5c - Francesco Caporale. Bust of António Manuel ne Vunda, 1629, polychrome marble. Santa Maria Maggiore Baptistery, Rome. Photograph: W.E.B. Du Bois Research Institute - Harvard University. 
25. Weaving in central Africa is a male activity.

26. Bassani; McLeod (2000).
Of Hats, Power, and History

The combination of local and foreign elements articulated in the entire outfits and in the swords also unfolded in the mpu caps that served as emblems of status in the Kongo. (Figure 6) The caps are among the best documented objects of early modern central African material culture through written and visual descriptions as well as examples that arrived in Europe as early as the seventeenth century. The orthogonal designs found on the caps were ubiquitous in Kongo visual culture and graced the surface of a wide range of objects from basketry to ivory horns and architecture. The elaboration and sophisticated variations of the designs suggest that they visually encoded complex information we can no longer decipher today.

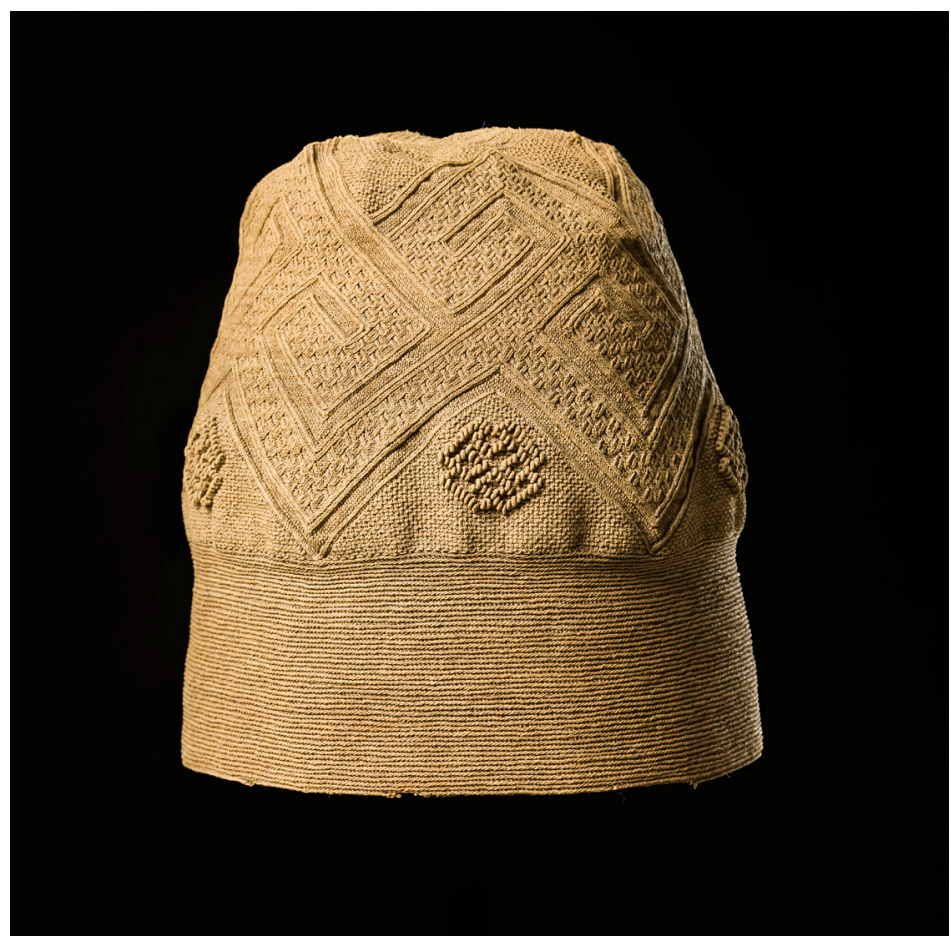

Figure 6 - Mpu cap of status. Kongo Kingdom, before 1674, vegetal fibers, height: $18 \mathrm{~cm}$. National Museum of Denmark, Copenhagen, inv. EDc123. Photograph courtesy of the National Museum of Denmark, Copenhagen.

The male artist who crafted the mpu in Figure 6 used the textile genre to create an unusual object, one among a handful that peculiar design variations set apart from the rest of the known corpus. ${ }^{25}$ The hat, now in Copenhagen's National museum, arrived in Europe before 1674 when it was catalogue in the Kunstkammer of the king of Denmark as a "cap of bast". ${ }^{26}$ The finely made Kongo textiles featured prominently among the treasures from near and far elite Europeans collected for their cabinets of curiosity. The itinerary the Copenhagen mpu followed is unknown, but it likely arrived in Europe either as a diplomatic gift sent from central Africa to Europe 
or as an item of trade. ${ }^{27}$ Juxtaposed to the main geometric motifs, on the lower part, five bold crosses appear above the textile ground in high relief. They stand in sharp contrast to the imbricate patterns in the rest of the hat that rise subtly above the main surface. The five crosses are repeated along the perimeter of the cap in a pattern that somewhat coordinates with the rhythm of the interlacing designs. They otherwise differ from these in almost all aspects. Unlike the rest of the patterns, the crosses are raised, finite, individual, and free floating. This distinct treatment suggests that the hat appealed to and ostentatiously combined distinct visual lexica. On the one hand, it used geometric interlaces, a sophisticated and ubiquitous central African genre of surface treatments. On the other hand, it called upon the singular motif of the cross which significance we may, at least partly, understand.

In 1696, the Capuchin Marcellino d'Atri saw during the coronation of Pedro IV a peculiar hat that functioned in a manner similar to the mpu. Coming to power in the midst of a civil war, the new king ascended to a much-weakened Kongo throne in a modest ceremony conducted on the site of the abandoned capital of São Salvador. Unable to use the European-style crown of his predecessors which was lost to the Portuguese in the disastrous 1665 battle of Mbwila, Pedro was coronated instead with a makeshift crown on which featured the royal coat of arms of the Kongo, as five unsheathed swords of shiny silver hue embroidered or pinned on the front of the headgear. The crown crafted for the occasion, seemingly cut from a European hat, replaced the gold-plated silver crown the pope had offered earlier to Kongo kings that had become essential to the royal regalia of the Christian central African monarchs at least since $1651 .{ }^{28}$

The substitution of the hat for the crown relied on the Kongo Christian correlation of local and foreign conceptions and manifestations of power and prestige. It concurrently drew from the intrinsic symbolic value of prestigious headgear such as mpu caps as a central African insignia of rulership and from the significance of the Kongo coat of arms as a potent emblem of royal power. Swords, as we recall, formed the central motif of the escutcheon adopted by Afonso circa 1500, where they evoked through heraldry the story of the triumph of Catholicism in the Kongo. The new king specifically linked the sword bearing arms in his gloss of the heraldic emblem as the "armed men that appeared in the sky [of the battle] to our rescue, who were angels". 29 Thereafter, Kongo rulers used the coat of arms on seals, regalia, and banners as symbols of their office.

With the addition of the heraldic signs, Pedro IV's lowly hat became a valid insignia of Kongo Christian kingship. The swords on the surface of the headgear functioned as other objects often attached to or designed on central African caps of status, such as claws, fangs, snakes, and feathers, which metaphorically attributed the skills of mighty animals to rulers. In a similar form of metonymy, the coat of arms on Pedro's hat linked its wearer to the supernatural powers of Saint James and his miraculous army of knights that enabled and sanctioned the rule of his Christian predecessors. The European-derived heraldic signs there became Kongo tropes. In other words, in Pedro's makeshift crown, the
27. Bassani (1983).

28. For discussion of the crown see Giacinto Brugiotti da Vetralla, in a 1655 account copied in the later manuscript by Monari da Modena (1723). Caltanisetta also mentions the golden crown in a 1651 coronation in APF, SOCG, vol. 249, ff. 431 v, 434 r - 435 v, see Caltanisetta; Bontinck (1970).

29. Brásio (1952). 
30. The cap appeared in a 1674 inventory, see Bassani; McLeod (2000).

31. For the Kimpasi see Cavazzi; Alamandini (1687), Montesarchio (ca.1668). For mourning see Lucca; Firenze (1700-1717), published in French in Cuvelier; Lucca (1953). imagery of the coat of arms functioned not only as a Portuguese-inspired emblem but also as a full-fledged Kongo metaphor that expressed conceptions of regal power honed in its foundation myth.

This episode allows us to understand that the political and symbolic changes that unfolded throughout the history of the kingdom did not adhere to a teleological pattern of acculturation or appropriation, in particular with regard to the kingdom's relationship to European ideas and objects. The kings of Kongo did not adopt the gilded European crown or other items of regalia only to emulate European rulers. And neither were the foreign objects fully taken over by local worldviews. Rather, they were part of a sophisticated reflection about the nature of power and legitimacy in the Kongo in the face of altered religious and material circumstances. And this reflection was one of correlation, transforming local logic and foreign input into intrinsically interrelated parts of a new whole. That a gilded crown may be used as a mpu and that later a locally crafted object may equally serve in place of an imported gilded crown showcases well the contingent, strategic, iterative, and cumulative path that Kongo Christianity followed from its advent circa 1500 and through centuries of dense history.

I believe that the cross mpu in Figure 6 functioned in a manner similar to the coronation hat. ${ }^{30}$ It combined low relief motifs typical of Kongo textiles with crosses in high relief, visibly distinct from its main pattern in the manner that the silver-colored swords were from the fabric of Pedro's hat-crown. As discussed above, the $x$-shape cross was a central motif in the visual and symbolic conversation between Kongo and Christian religious thought. In the realm of Christianity, it recalled the narrative of Christ's death on the cross and subsequent resurrection. In the Kongo it marked, before and after contact with Europeans, space in which the world of the living and that of the dead became permeable. The sign of the cross thus served as emblem for associations defined by their ability to trespass the limits between life and death such as Kimpasi, or mourners would seek crossroads as areas to perform the rituals made necessary by the incursion of death in life. ${ }^{31}$ In tombstones, crucifixes, and medals, the sign, often combined to the Latin cross as it is in Figure 4, brought together Christian and central African notions of life, death, and immanence. The symbols on the mpu clearly associated the cap with these ideas. Yet the signs also functioned as the swords on Pedro's hat or the animal claws present on other examples that is to say as emblems qualifying the nature and origins of their wearer's prestige. In this case, their distinct hollow branches linked its noble wearer to the Order of Christ.

The Order of Christ was introduced to central Africa in the first moments of contact with Europe and soon became a staple of the kingdom's political life. Early modern depictions and archeological evidence placed the Order's insignia, a cross with hollow branches of equal length, among the most prominent regalia of the central African elite. Precious metal medallions such as the one recovered at the eighteenth century cemetery of Ngongo Mbata or depicted on the chest of the Kongo king Portuguese chronicler Cadornega painted in the 1680s, embroideries 
on the coats of the rulers as seen in the Missione in Prattica vignettes, wax seals and signatures in the autograph correspondence of the elite, rock painting and engravings all heralded the emblem of the Order. ${ }^{32}$

Attached to the cap as lion claws or other badges of prestige, they turned the mpu into an emblem of Christian nobility. Placed on the central African cap, they also became central African metaphors of the power and legitimacy that the cap's wearer derived from Christianity and its invisible realm. Here again, in successive, cumulative strokes, ideas and motifs linked to both Kongo and European religious and political thought met, blurred and, eventually, redeployed into a single, cohesive object.

The Look of Sainthood

Furthermore, the ideas of religious affiliation reflected in Kongo elite sartorial practices further emphasized their political standing and social prestige. Eeckhout's images in Figure 2 captured the Kongo elite's enthusiastic adoption of medals, rosaries, and crosses wrapped around the necks of fortunate men in spectacular displays of wealth as well as religious attachment. Catholic paraphernalia functioned within the early modern Kongo in a very similar manner as other imports, as precious rarities alluding to privilege, wealth, and power. Metallographic analysis will confirm or disprove this hypothesis, but it is very likely that many of the Kongo Christian objects were created with imported metal. The imported brass trade goods reappeared in the medals, chains, and crosses of the Kongo ouffits. The transformation of imported metal into central African artefacts illustrates once more the complex, non-linear processes through which Kongo Christian visual culture emerged. Central African metal workers transformed European brass items into Kongo objects. But these Kongo objects were crucifixes and saint figures that, of course, drew their form from earlier operations of religious and artistic appropriation and correlation that had naturalized Christ and the saints into local characters. In this circular and cumulative operation of transformation and appropriation, ideas of wealth and power but also visual manifestations of prestige and Christianity became mutually reinforcing. This link, what is more, was not only abstract.

Brass saints worn as pendants were a common sight in the Christian Kongo. Precious metal objects collected in the twentieth century, about three inches tall and distinguished by a suspension loop at their back, offer exquisitely detailed depictions of richly dressed figures understood to represent Saint Anthony on iconographic grounds as well as in light of twentieth century identifications. They depict Saint Anthony in typical Capuchin garb and are likely seventeenth and eighteenth century objects passed down through generations or more recent creations carefully recast from older prototypes. ${ }^{33}$ The popularity of the figures in the historical kingdom not only demonstrated the interest of the Kongo elite in Christian devotional objects, but also materialized the connection between Christianity and social and political prestige.
32. For a history of the Order of Christ in the Kongo see L'Hoist (1932). See the emblem on king Afonso's 1517 seal in Arquivo Nacional da Torre do Tombo, Lisbon, Corpo Cronológico, 1 21 109, on the frontispiece of Cadornega (1680), on the signature of the ruler of Soyo in Arquivo Nacional da Torre do Tombo, Lisbon, Corpo Cronológico, II 92 142 , in rock painting and engraving published in Raymaekers; Moorsel (1964).

33. Wannyn (1961). 
The Saint Anthony in Figure 7, now in the Metropolitan in New York, stands hieratically on a pedestal, and expectedly holds in his right hand a hollowed cross and in the other, the child Christ on a book. His tonsure, the carefully molded hood on his otherwise bare back and the knotted cord he wears as a belt make him a convincing representation of the Franciscan saint.

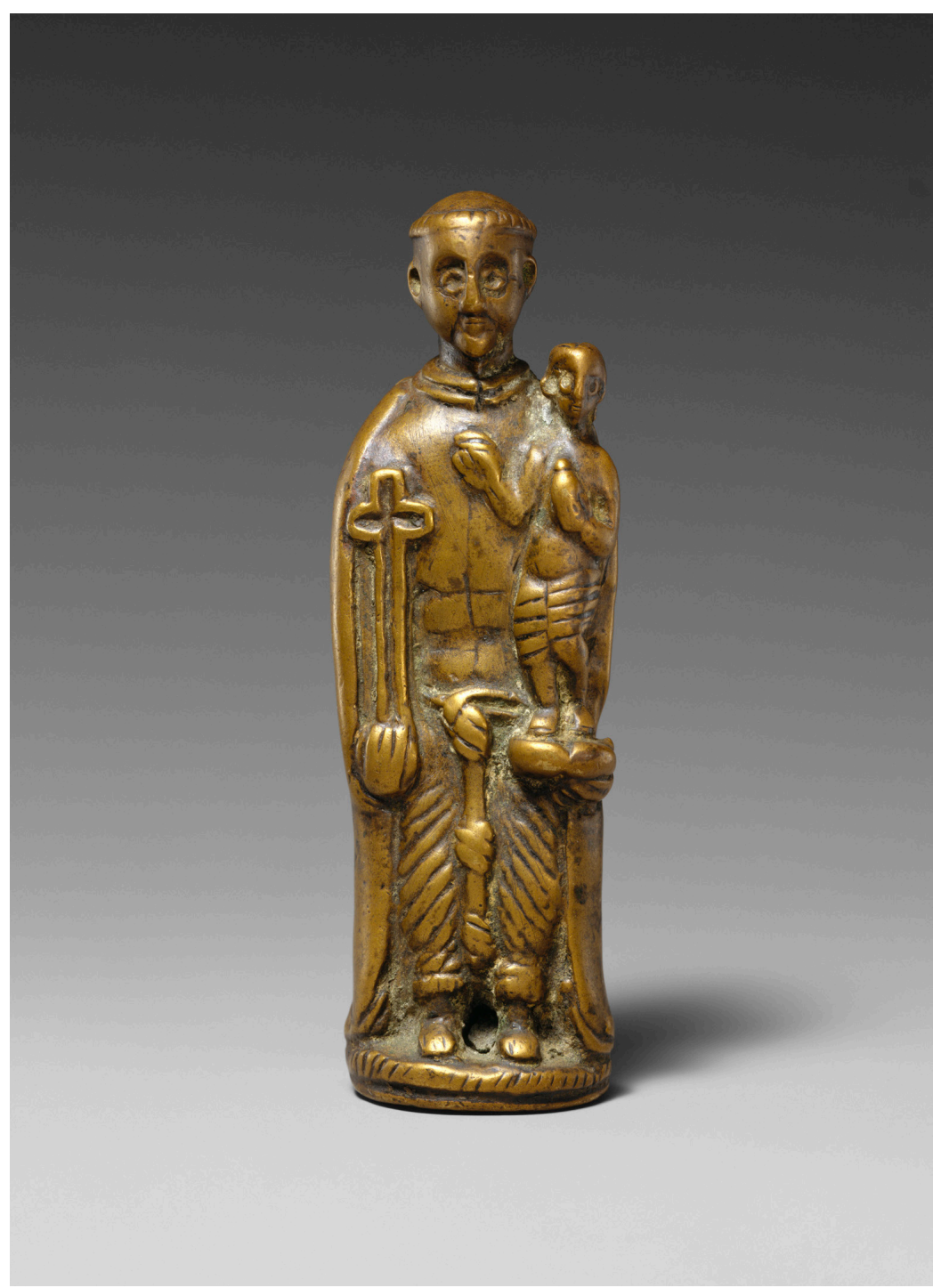

Figure 7 - Saint Anthony figure. Kongo Kingdom, possibly 17th - 18th century. Brass, height: 10 cm. The Metropolitan Museum of Art. Gift of Ernst Anspach, 1999, inv. 1999.295. 1. Photograph: (C) The Metropolitan Museum of Art.

But notice how the folds of his habit fall around his shoulders as a cape and drape around his legs as a wrapper. Incisions on his chest also suggest a muscular, bare torso. Is he Saint Anthony or a Kongo noble in full regalia that could readily join the ranks of the elite men depicted in friar Bernardino's watercolor? Isn't 
the bi-colored cross he holds that of the Order of Christ? Maybe his tonsure is an mpu, his knotted belt a red sash.

The pendants, but also medals, and crucifixes featuring similar imagery, all captured the remarkable fluidity that existed between the appearance of the elite and representations of their saints. The ambiguity certainly contributed to make the distant holy men more familiar figures. But the presence of the same regalia also made manifest the three way connection between power, wealth, and Christianity. And this link was also highly visible as elite men and women wore the brass figurines, medals, swords, and crucifixes as part of their finery so that figures and wearers visually echoed each other, in a mise en abyme that visualized and further reinforced the connection.

In conclusion, more than a combination of mismatched pieces, Kongo Christian regalia formed a cohesive whole in which the symbols of prestige borrowed from Europe, as well as Christianity altogether, entered into a complex and evolving dialogue with preexisting local visual expressions of might and prestige, and their concomitant mythological and religious base. The Kongo elite correlated in cumulative and interlacing streams objects and ideas that expressed their status as Christian nobles and participants in the Atlantic World while making sense of these changes according to their own worldview. Clothing and regalia offered one of the spaces of correlation within which this sophisticated conversation between the Kongo people's religious, political, and historical thought and the novelties brought to their shore by an expanding world unfolded. A mpu cap becoming an emblem of Christian knighthood, a brass saint turning into a central African nobleman, or an Iberian-style sword portraying a Kongo ruler all showcase the inward-looking reflection through which the men and women of the Kongo embraced religious and material novelties and made them their own in the cradle of the early modern Atlantic World. 


\section{REFERENCES}

\section{MANUSCRIPT SOURCES}

CADORNEGA, António de Oliveira de. História Geral das Guerras Angolanas. Lisboa: Academia das Ciências, 1680.

D'ASTI, Bernardino Ignazio da Vezza. Missione in prattica de RP cappuccini italiani ne regni di Congo, Angola, et adiacenti. Vaticano: Biblioteca Vaticana, [ca.1750].

EECKHOUT, Albert van der; MENTZEL, Christian. Icones animalium Brasiliae. Theatri rerum naturalium brasiliae tomus III quo pronuntur icons animalium ad bomine ad insecta usq iussu serenissimi ac potentissimi principis ac domini Dn Friderici Wilhelmi, marchionis brandeburgici, S R IMP archicamerarii atq electoris principis $\& c$ \&c $\mathcal{E} c$ in ordinem redactus a Christiano Menszelio D. Krakow: Biblioteka Jagiellonska, 1637-1644a.

; __ Theatrum Rerum. Krakow: Biblioteka Jagiellonska, 1637-1644b.

GODINHO, Antonio. Livro da Nobreza Perfecao das Armas dos Reis Cristaos e Nobres Linhagens dos Reinos e Senhorios de Portugal, MS. Casa Forte 164. Lisboa: Instituto dos Arquivos Nacionais - Torre do Tombo, 1528-1541, fólio 7.

GUATTINI, Michele Angelo; CARLI, Dionigi; SURDICH, Francesco. Viaggio nel Regno del Congo. Cinisello Balsamo (Milano): San Paolo, 1997.

LUCCA, Lorenzo da; FIRENZE, Filippo da. Relazioni d'alcuni Missionari Capp:ni Toscani singolarmente del P. Lorenzo da Lucca che due volte fù Miss:io Apotol:co al Congo. Parte Seconda. Florence: Archivio Provinciale dei Frati Minori Cappuccini della Provincia di Toscana, 1700-1717.

MONARI DA MODENA, Giuseppe. Viaggio al Congo, fatto da me fra Giuseppe da Modena Missionario Apostolico e predicatore Capuccino, incomentato alli 11 del mese di Novembre del anno 1711, e terminato alli 22 di Febraro del anno 1713 etc... Modena: Biblioteca Estense, 1723.

MONTESARCHIO, Girolamo da. Viaggio al Gongho. Florence: Fondo Missioni Estere, [ca.1668].

\section{PRINTED SOURCES}

BAERLE, Caspar van; BRANDÃO, Claudio. História dos feitos recentemente praticados durante oito anos no Brasil e noutras partes sob o govêrno do ilustríssimo João Maurício. Rio de Janeiro: Serviço Gráfico do Ministério de Educação, 1940.

CAVAZZI, Giovanni Antonio; ALAMANDINI, Fortunato. Istorica descrizione de' tre regni Congo, Matamba et Angola sitvati nell' Etiopia inferiore occidentale e delle missioni apostoliche esercitateui da religiosi Capuccini. Bologna: Giacomo Monti, 1687. 
DAPPER, Olfert. Naukeurige beschrijvinge der afrikanensche eylanden; als Madagaskar, of Sant Laurens, Sant Thomee, d'eilanden van Kanarien, Kaep de Verd, Malta en andere, vertoont in de benamingen, gelegentheit, steden, revieren, gewassen Ec. Amsterdam: [s.n.], 1668.

LOPES, Duarte; PIGAFETTA, Filippo. Relatione del reame di Congo et delle circonvicine contrade, tratta dalli scritti E ragionamenti di Odoardo Lopez, Portoghese. Roma: Appresso B. Grassi, 1591.

MEROLLA DA SORRENTO, Girolamo; PICCARDO, Angelo. Breve, e svccinta relatione del viaggio nel regno di Congo nell' Africa meridionale, fatto dal P. Girolamo Merolla da Sorrento ... Continente variati clima, arie, animali, fiumi, frutti, vestimenti con proprie figure, diuersita di costumi, e di viueri per l'vso humano. Napoli: Per F. Mollo, 1692.

NIEUHOF, Johan. Joan Nieubofs Gedenkwaerdige zee en lantreize door de voornaemste landschappen van West en Oostindien. Amsterdam: By de weduwe van Iacob van Meurs, 1682. 2. v.

ROMA, Giovanni Francesco da. Breve Relatione del succeso della missione de frati minori cappuccini del serafico p s. francesco al regno del congo e delle qualita, costumi, maniere di vevere di quel regno, e suoi habitatori. Roma: Nella Stampa della Sacra Congregazione de Propaganda Fide, 1648.

BOOKS, ARTICLES, AND THESIS

ARTELT, Walter. The "Theatrum Rerum Naturalium Brasiliae" of 1660. In: (Ed.). Actes du X Congrès international d'bistoire des sciences. Paris: [s.n.], 1964, p. 925-926. 2. v.

BASSANI, Ezio. A note on Kongo high-status caps in old European collections. Res, v. 5, p. 75-84, 1983.

; MCLEOD, Malcolm. African art and artefacts in European collections: 1400-1800. London: British Museum, 2000.

BETHENCOURT, Francisco; CURTO, Diogo Ramada. Portuguese oceanic expansion, 1400-1800. Cambridge (UK); New York: Cambridge University Press, 2007.

BRÁSIO, António. Monumenta missionaria africana. Africa ocidental. Lisboa: Agência Geral do Ultramar; Divisão de Publicações e Biblioteca, 1952. 15 v.

BONTINCK, François; ROMA, Giovanni Francesco da. La fondation de la mission des Capucins au Royaume du Congo (1648). Louvain; Paris: Nauwelaerts, 1964.

BRIENEN, Rebecca Parker; EECKHOUT, Albert van der. Visions of savage paradise: Albert Eckhout, court painter in colonial Dutch Brazil. Amsterdam: Amsterdam University Press, 2006. 
CALTANISETTA, Luca da; BONTINCK, François. Diaire congolais. 1690-1701. Louvain, Paris: Éditions Nauwelaerts; Béatrice-Nauwelaerts, 1970.

CLIST, Bernard; CRANSHOF, Els; SCHRYVER, Gilles-Maurice de; HERREMANS, Davy; KARKLINS, Karlis; MATONDA, Igor; STEYAERT, Fanny; BOSTOEN, Koen. African-European Contacts in the Kongo Kingdom (16th-18th c.): New Archaeological Insights from Ngongo Mbata (Lower Congo, DRC). International Journal of Historical Archaeology, v. 19, 2015.

CUMMINS, Thomas. From lies to truth: Colonial Ekphrasis and the Act of Crosscultural Translation. In: FARAGO, Claire (Ed.). Reframing the Renaissance. New Haven; London: Yale Univeristy Press, 1995. p.152-174, 326-329.

CUVELIER, Jean; LUCCA, Lorenzo da. Relations sur le Congo du père Laurent de Lucques (17001717). Bruxelles: Institut Royal Colonial Belge, 1953.

FROMONT, Cécile. Collecting and Translating Knowledge Across Cultures: Capuchin Missionary Images of Early modern Central Africa. In: BLEICHMAR, Daniela; MANCALL, Peter (Ed.). Collecting Across Cultures: Material Exchanges in the Early Modern Atlantic World. Philadelphia: University of Pennsylvania Press, 2011a, p. 134-154, 311-315.

. Dance, Image, Myth, and Conversion in the Kingdom of Kongo: 1500-1800. African Arts, v. 44, n. 4, p. 52-63, 2011 b.

. Under the Sign of the Cross in the Kingdom of Kongo: Religious Conversion and Visual Correlation in Early Modern Central Africa. RES: Anthropology and Aesthetics, n. 59-60, p. 109123, 2011c.

The Art of Conversion: Christian Visual Culture in the Kingdom of Kongo. Chapel Hill: University of North Carolina Press, 2014.

HEUSCH, Luc de. Le roi ivre; ou L'origine de l'État; mythes et rites bantous. Paris: Gallimard, 1972 .

HEYWOOD, Linda Marinda; THORNTON, John Kelly. Central Africans, Atlantic Creoles, and the foundation of the Americas, 1585-1660. Cambridge (UK); New York: Cambridge University Press, 2007.

HILTON, Anne. The kingdom of Kongo. Oxford; New York: Clarendon Press; Oxford University Press, 1985.

JADIN, Louis. Aperçu de la situation du Congo et rite d'élection des rois en 1775, d'apres le P. Cherubino da Savona. Bulletin de l'Institut Historique Belge de Rome, v. 35, p. 33-454, 1963.

JADIN, Louis. Andrea de Pavia au Congo, à Lisbonne, à Madère. Journal d'un missionnaire capucin, 1685-1702. Bulletin de l'Institut Historique Belge de Rome, n. XLI, p. 375-592, 1970. 
KAPLAN, Paul H. D. Italy, 1490-1700. In: GATES, Henry Louis; BINDMAN, David (Ed.). The Image of the Black in Western Art from the "Age of Discovery" to the Age of Abolition: Artists of the Renaissance and Baroque. Cambridge (USA): Harvard University Press, v. III, part. 1, p. 93-190, 2010.

L'HOIST, André. L'ordre du Christ au Congo. Revue de l'Aucam, v. VII, p. 258-266, 1932.

LEGUZZANO, Graziano Maria Saccardo da. Congo e Angola con la storia dell'Antica missione dei Cappuccini. Venezia-Mestre: Curia Povinciale dei Cappuccini, 1982-1983.

PIAZZA, Calogero. La missione del Soyo (1713-1716) nella relazione inedita di G. da Modena OFM Cap. Roma: L'Italia Francescana, 1973.

RADULET, Carmen; PINA, Rui de. O cronista Rui de Pina e a "Relação do Reino do Congo": manuscrito inédito do "Códice Riccardiano 1910". Lisboa: Comissão Nacional para as Comemorações dos Descobrimentos Portugueses; Imprensa Nacional - Casa da Moeda, 1992.

RAYMAEKERS, Paul; MOORSEL, Hendrik van. Lovo, contribution à l'étude de la protobistoire de l'Ouest centrafricain. [Léopoldville]: Editions de l'Université de Léopoldville, 1964.

; BONTINCK, François. Brève relation de la fondation de la mission des frères mineurs capucins du séraphique père saint François au Royaume du Congo, et des particularités, coutumes et façons de vivre des habitants de ce royaume. Louvain; Paris: Éditions Nauwelaerts, 1964.

VANDENHOUTE, Johan. De Begraafplaats van Ngongo-Mbata (Neder-Zaire) (licentiaat in de kunstgeschiedenis en Oudheidkunde). Gand: Rijksuniversiteit Gent Hoger Instituut voor Kunstgesischiedenis on Oudheidkunde, 1972-73.

VANSINA, Jan. Kingdoms of the savanna. Madison: University of Wisconsin Press, 1966.

WANNYN, Rob. L'art ancien du métal au Bas-Congo. Champles par Wavre (Belgique): Éditions du Vieux Planquesaule, 1961.

Artigo apresentado em $01 / 11 / 2016$. Aprovado em 26/02/2017 